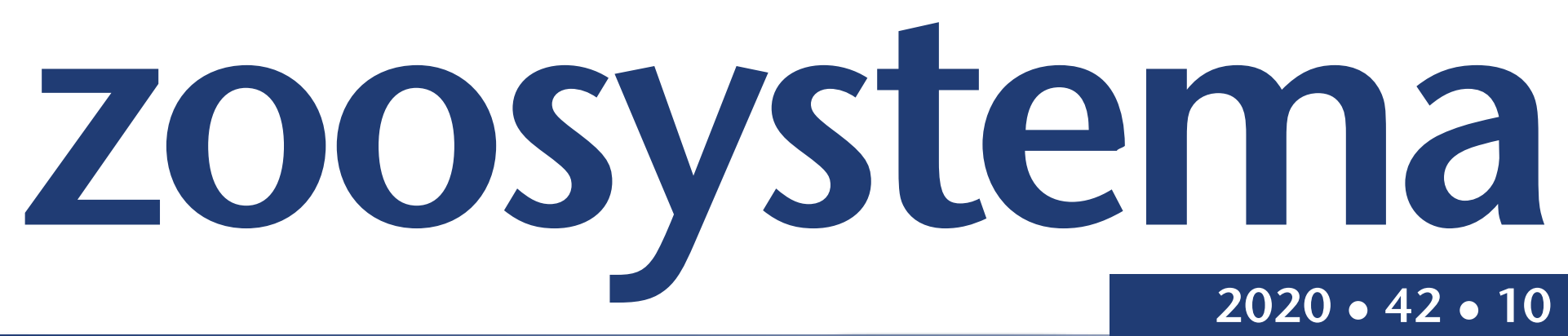

"OUR PLANET REVIEWED" 2015

LARGE-SCALE BIOTIC SURVEY IN MITARAKA, FRENCH GUIANA Edited by Julien TOUROULT

Descriptions of two new genera of Maruinini (Diptera, Psychodidae, Psychodinae) from the Mitaraka range of French Guiana

Gregory CURLER

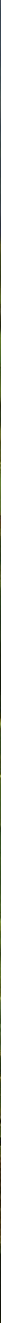


DiRECTEUR DE LA PUBlication: Bruno David

Président du Muséum national d'Histoire naturelle

RÉDACTRICE EN CHEF / EDITOR-IN-CHIEF : Laure Desutter-Grandcolas

AsSISTANTS DE RÉDACTION / AssISTANT EDITORS : Anne Mabille (zoosyst@mnhn.fr)

Mise en PAge / PAge LAYOUt: Anne Mabille

COMITÉ SCIENTIFIQUE / SCIENTIFIC BOARD:

James Carpenter (AMNH, New York, États-Unis)

Maria Marta Cigliano (Museo de La Plata, La Plata, Argentine)

Henrik Enghoff (NHMD, Copenhague, Danemark)

Rafael Marquez (CSIC, Madrid, Espagne)

Peter Ng (University of Singapore)

Norman I. Platnick (AMNH, New York, États-Unis)

Jean-Yves Rasplus (INRA, Montferrier-sur-Lez, France)

Jean-François Silvain (IRD, Gif-sur-Yvette, France)

Wanda M. Weiner (Polish Academy of Sciences, Cracovie, Pologne)

John Wenzel (The Ohio State University, Columbus, États-Unis)

COUVERTURE / COVER:

View of Sommet en Cloche in the Mitaraka massif (photo: Maurice Leponce). In medallion: photomicrographs of Polletomyia subulata n. gen., n. sp. male wings.

\author{
Zoosystema est indexé dans / Zoosystema is indexed in: \\ - Science Citation Index Expanded (SciSearch ${ }^{\circledR}$ ) \\ - ISI Alerting Services ${ }^{\circledR}$ \\ - Current Contents ${ }^{\circledR} /$ Agriculture, Biology, and Environmental Sciences ${ }^{\circledR}$ \\ - Scopus ${ }^{\circledR}$
}

Zoosystema est distribué en version électronique par / Zoosystema is distributed electronically by:

- BioOne ${ }^{\circledR}$ (http://www.bioone.org)

Les articles ainsi que les nouveautés nomenclaturales publiés dans Zoosystema sont référencés par / Articles and nomenclatural novelties published in Zoosystema are referenced by:

- ZooBank ${ }^{\circledR}$ (http://zoobank.org)

Zoosystema est une revue en flux continu publiée par les Publications scientifiques du Muséum, Paris / Zoosystema is a fast track journal published by the Museum Science Press, Paris

Les Publications scientifiques du Muséum publient aussi / The Museum Science Press also publish:

Adansonia, Geodiversitas, Anthropozoologica, European Journal of Taxonomy, Naturae, Cryptogamie sous-sections Algologie, Bryologie, Mycologie.

Diffusion - Publications scientifiques Muséum national d'Histoire naturelle

CP 41 - 57 rue Cuvier F-75231 Paris cedex 05 (France)

Tél. : 33 (0)1 40794805 / Fax: 33 (0)1 40793840

diff.pub@mnhn.fr / http://sciencepress.mnhn.fr

(C) Publications scientifiques du Muséum national d'Histoire naturelle, Paris, 2020

ISSN (imprimé / print): 1280-9551/ ISSN (électronique / electronic): 1638-9387 


\title{
Descriptions of two new genera of Maruinini (Diptera, Psychodidae, Psychodinae) from the Mitaraka range of French Guiana
}

\author{
Gregory CURLER \\ Mississippi Entomological Museum, Mississippi State University, \\ 100 Old Highway 12, P.O. Drawer 9775, Mississippi State, MS 39762-9775 (USA) \\ Research Collaborator, Smithsonian Institution, National Museum of Natural History; \\ $10^{\text {th }}$ \& Constitution NW, Washington, DC 20560-0169 (USA) \\ gcurler@gmail.com
}

Submitted on 10 January 2018 | Accepted on 15 October 2019 | Published on 7 April 2020

KEY WORDS Neotropical Region, biodiversity, new genus, new species.

MOTS CLÉS Région néotropicale, biodiversité, genres nouveaux espèces nouvelles.
urn:Isid:zoobank.org:pub:21B9187A-D055-4946-8922-53FD10A159CE

Curler G. 2020. - Descriptions of two new genera of Maruinini (Diptera, Psychodidae, Psychodinae) from the Mitaraka range of French Guiana, in Touroult J. (ed.), "Our Planet Reviewed" 2015 large-scale biotic survey in Mitaraka, French Guiana. Zoosystema 42 (10): 139-149. https://doi.org/10.5252/zoosystema2020v42a10. http://zoosystema.com/42/10

\section{ABSTRACT}

Little information is available regarding the non-phlebotomine Psychodidae Newman, 1834 of French Guiana. Psychodid specimens were sorted from samples collected during the recent "Our Planet Reviewed" Guyane-2015 expedition in the Mitaraka range. Males and females of two genera of tribe Maruinini Enderlein, 1937, Polletomyia subulata n. gen., n. sp. and Myiomystax trilineata n. gen., n. sp., are described and illustrated. Characters pertinent to assessing relationships among genera of Maruinini are discussed.

\section{RÉSUMÉ}

Description de nouveaux genres de Maruinini (Diptera, Psychodidae, Psychodinae) dans les environs du Mitaraka en Guyane.

Peu d'informations sont disponibles concernant les Psychodidae Newman, 1834 de Guyane autres que les phlébotomes. Des spécimens de psychodides ont été triés à partir d'échantillons prélevés lors de la récente expédition "La Planète revisitée» Guyane-2015 dans la chaîne de Mitaraka. Les mâles et les femelles de deux genres de la tribu Maruinini Enderlein, 1937, Polletomyia subulata n. gen., n. sp. et Myiomystax trilineata n. gen., n. sp., sont décrits et illustrés. Les caractères pertinents pour évaluer les relations entre les genres de Maruinini sont discutés. 


\section{INTRODUCTION}

Psychodidae Newman, 1834 (moth flies and sand flies), currently with six recognized subfamilies, are cosmopolitan in distribution, occupying a broad range of niches (Curler \& Moulton 2012). In the Neotropical region, subfamily Phlebotominae Rondani, 1840 is best known due to their significance as vectors of disease agents such as Leishmania Ross, 1903 parasites (Young \& Duncan 1994; Galati 2019). The remaining subfamilies have received relatively little attention. In particular, a majority of the non-phlebotomine psychodid fauna of French Guiana remains unknown. Indeed, Psychodinae Newman, 1834 is the only other subfamily reported from the country; Quate \& Brown (2004) provided details of these records. In summary, a total of four genera and 12 species of tribe Maruinini Enderlein, 1937 are known to occur in French Guiana: Alepia Enderlein, 1937 is represented by four species (A. piscicauda Quate \& Brown, 2004; A. diocula Quate \& Brown, 2004; A. fruticosa Quate \& Brown, 2004; and A. bisubulata Duckhouse, 1968); Balbagathis Quate, 1996 by one species (B. agrestis Quate \& Brown, 2004); Tonnoira Enderlein, 1937 by three species (T. sicilis Quate \& Brown, 2004; T. didyma Quate \& Brown, 2004; T. cavernicola Quate \& Brown, 2004); and Caenobrunettia Wagner, 1981 by four species (C. subditicia Quate \& Brown, 2004; C. laselva Quate, 1996; C. echinoflagellata Wagner, 1981; and C. fraudulenta Quate \& Brown, 2004). Recently, an expedition in the Mitaraka range of French Guiana Amazonian Park resulted in the collection of nearly 400 specimens of Psychodidae, including two undescribed genera of Maruinini. These two genera are described and illustrated here.

\section{MATERIAL AND METHODS}

\section{STUDY AREA}

All Psychodidae examined as part of this study were collected during the "Our Planet Reviewed" Guyane-2015 expedition in the Mitaraka range, in the core area of the French Guiana Amazonian Park, organized by the MNHN and Pro-Natura international (Touroult et al. 2018).

\section{COLLECTION AND OBSERVATION}

Most specimens were collected by pan traps (yellow, white or blue pans) while few were also sampled in a Malaise trap or randomly using a sweep net. The biological sampling benefited from the access and benefit sharing agreement "APA973-1", which is reported in each sample label. All specimens were preserved in 70 or $95 \%$ ethanol, subsequently macerated in cold $8 \%$ potassium hydroxide $(\mathrm{KOH})$, dehydrated in ethanol, transferred to xylene and finally mounted in Canada balsam. Observations and measurements were completed using an Olympus BX50 compound microscope equipped with differential interference contrast, and a Wild M5 stereomicroscope fitted with an ocular micrometer. Drawings were rendered with the aid of a drawing tube on the Olympus system. Photomicrographs were captured using a Nikon DS-Fil camera mounted on a Nikon Eclipse E800 compound microscope.
Focus stacks were created using Zerene Stacker (Build T-201807-19-1515) and images were optimized for color and clarity using Adobe Lightroom ${ }^{\circ} \mathrm{CC}$ and Adobe Photoshop ${ }^{\circ}$ CS6.

\section{MEASUREMENTS}

Head width was measured at the point of greatest width of the eyes. Adult head height was measured from the vertex to the anterior margin of the clypeus. Approximate wing length and width were measured at the points of greatest length and width of the dissected wing. Sample sizes are provided before each description with measurements in millimeters presented as a mean followed by a range in parentheses.

\section{TERMINOLOGY}

General terminology follows Cumming \& Wood (2017), except interpretation of wing venation, which is that of Krzemiński \& Krzemińska (2003). Most Psychodidae have hyaline sensilla, variable in shape, inserted on some or all their antennal flagellomeres; these are termed "ascoids" (Kvifte \& Wagner 2017). Specific characters of the male terminalia (e.g. gonocoxal apodemes) are described here according to the interpretation of Duckhouse (1990) as followed by Quate \& Brown (2004). The elongate lobes articulated posteriorly with the epandrium in Psychodinae are referred to here as "epandrial claspers" sensu Dos Santos \& Curler (2014). Both "lateral arm of subepandrial sclerite" and "dorsal paramere" are terms that have not been applied previously for Psychodidae, but are used here provisionally to describe specific parts of the male genitalia.

\section{TAXONOMY}

Specimens examined during this study were identified or determined as new to science based on keys and generic diagnoses provided by Quate \& Brown (2004). Nonetheless, the tribal classification used in that work (i.e., Setomimini Vaillant, 1982) is not followed here, as Setomimini is a junior synonym of Maruinini. Duckhouse (1990) provided a diagnosis for Maruinini.

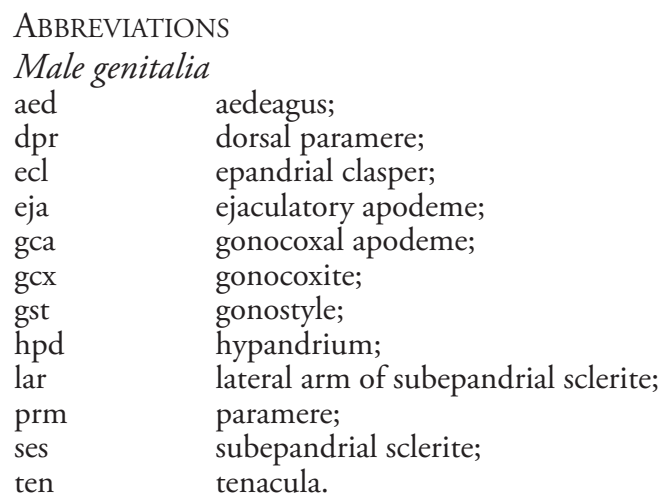

\section{Female genitalia}

st8 abdominal sternum 8;

ovd oviduct.

\section{General morphology \\ asc ascoid;}




$\begin{array}{ll}\text { Wing venation } & \\ \mathrm{CuA} & \text { anterior cubital vein; } \\ \mathrm{M} & \text { medial vein; } \\ \mathrm{R} & \text { radial vein; } \\ \mathrm{Sc} & \text { subcostal vein. }\end{array}$

Repository

MNHN Muséum national d'Histoire naturelle, Paris;

LACM Natural History Museum of Los Angeles County, Los Angeles, CA.

$\begin{array}{ll}\text { Collecting methods } \\ \text { BPT } & \text { blue pan trap; } \\ \text { YPT } & \text { yellow pan trap; } \\ \text { WPT } & \text { white pan trap; } \\ \text { SLAM } & \text { square Malaise trap; } \\ \text { SW } & \text { sweep net. }\end{array}$

\section{RESULTS}

Most of the approximately 400 specimens collected from Mitaraka represent undescribed taxa. Nonetheless, a majority of this material was not included in the present report, but will be treated in subsequent papers. Adequate series of males and females of two undescribed genera of Maruinini were among the collected material, allowing for the following descriptions.

\section{Subfamily PSYCHODINAE Newman, 1834 Tribe MARUININI Enderlein, 1937}

$$
\text { Genus Polletomyia n. gen. }
$$

\section{urn:Isid:zoobank.org:act:3869FC8A-73CD-4F9D-BBA1-F00A5BA77F4C}

TYPE SPECIES. - Polletomyia subulata n. gen., n. sp.

Illustrations. — Head: Fig. 1A; Wing: Fig. 1B; Male genitalia: Fig. 1E-G.

Etymology. - This genus is named in honor of Dr Marc Pollet, who collected the type specimens, forwarded them to the author and provided supporting information during the course of this study.

DiAGNOSIS. - The following combination of characters is diagnostic for the genus: male head: antennal flagellomeres fusiform, with paired, unbranched ascoids on $\mathrm{f} 4 \mathrm{f} 7$ (Fig. 1C), single ascoids on f8 f11; male terminalia: bilaterally symmetrical; aedeagus comprised of four movable, blade-like sclerites surrounded by membranous sheath; outer aedeagal sclerites sinuous, spreading laterally when extended posteriorly (Fig. 1F); gonostyli with stout, conical setae inserted apically (Fig. 1E-G); epandrial claspers each with single, setiform tenaculum inserted dorsoapically (Fig. 2B).

Distribution. - Polletomyia n. gen. is currently known only from the Mitaraka range of French Guiana.

HАВITAT. - Little information regarding specific habitat is available; however, all specimens were collected in lowland rainforest.

\section{REMARKS}

The relatively small size of Polletomyia n. gen., as well as their lanceolate wings and dark coloration make it possible to differentiate them in a sample comprised of many psychodid genera and species. These superficial characters also make it possible to associate males and females, as the latter are otherwise lacking in characters that readily differentiate them from other psychodine females. Indeed, if further species of Polletomyia n. gen. are discovered, it may become difficult or impossible to differentiate females within the genus. Despite the relative ease of differentiating them in a bulk sample, accurate diagnosis of this genus is dependent on examination of slide-mounted male terminalia.

Currently, the following character states are sufficient for distinguishing this genus from all other Maruinini: male terminalia bilaterally symmetrical; gonostyli each with a conical, spiniform seta inserted apically; tenacula setiform. Nonetheless, additional characters are included above in the diagnosis because they are also unique to the genus, thereby making the diagnosis more robust. Some other genera of Maruinini also have bilaterally symmetrical male terminalia in some or all constituent species (e.g. Alepia, Caenobrunettia, Maruina Müller, 1895, and Myiomystax n. gen.). Yet, each of these groups has a unique build to their aedeagus that is distinct from Polletomyia n. gen. and none of them have conspicuous, spiniform setae inserted at the apices of their gonostyli.

Aside from the male terminalia, some character states present in Polletomyia n. gen. are found as well in other genera of Maruinini, such as a contiguous eye bridge comprised of three rows of ommatidia. These states are also present in Maruina (so far only in subgenus Aculcina Hogue, 1973) and Arisemus Satchell, 1955 and have been indicated by some authors as diagnostic for those genera (e.g. Camico et al. 2019: 298 in their diagnosis of $M$. (Aculcina)). Despite this, the presence of these character states in multiple genera indicates that they are not diagnostic in and of themselves. Rather, it is necessary to determine whether there are other nuances that distinguish the eye bridge of each genus from others that have the same general appearance. In the case of Polletomyia n. gen., the eye bridge is not particularly distinct, so it is omitted as a diagnostic character.

\section{DESCRIPTION}

See below, Polletomyia subulata n. gen., n. sp.

Polletomyia subulata n. gen., n. sp.

(Figs $1 ; 2 ; 5 \mathrm{~A}$ )

urn:Isid:zoobank.org:act:E67019D9-A3A3-4A9C-9CC4-CE6279752520

TyPE LOCALITY. — Guyane, Mitaraka.

TYPE MATERIAL. - Holotype. French Guiana $0^{7}$; Mitaraka, site MIT-C-RBF2; $02^{\circ} 14^{\prime} 03.4^{\prime \prime N}, 5^{\circ} 26^{\prime} 53.0^{\prime \prime W} ; 29$ m a.s.l.; lowland rainforest; 27.II-6.III.2015; Marc Pollet leg. (sample code: MITARAKA/125), YPT; specimen dissected, mounted on slide; MNHN. 


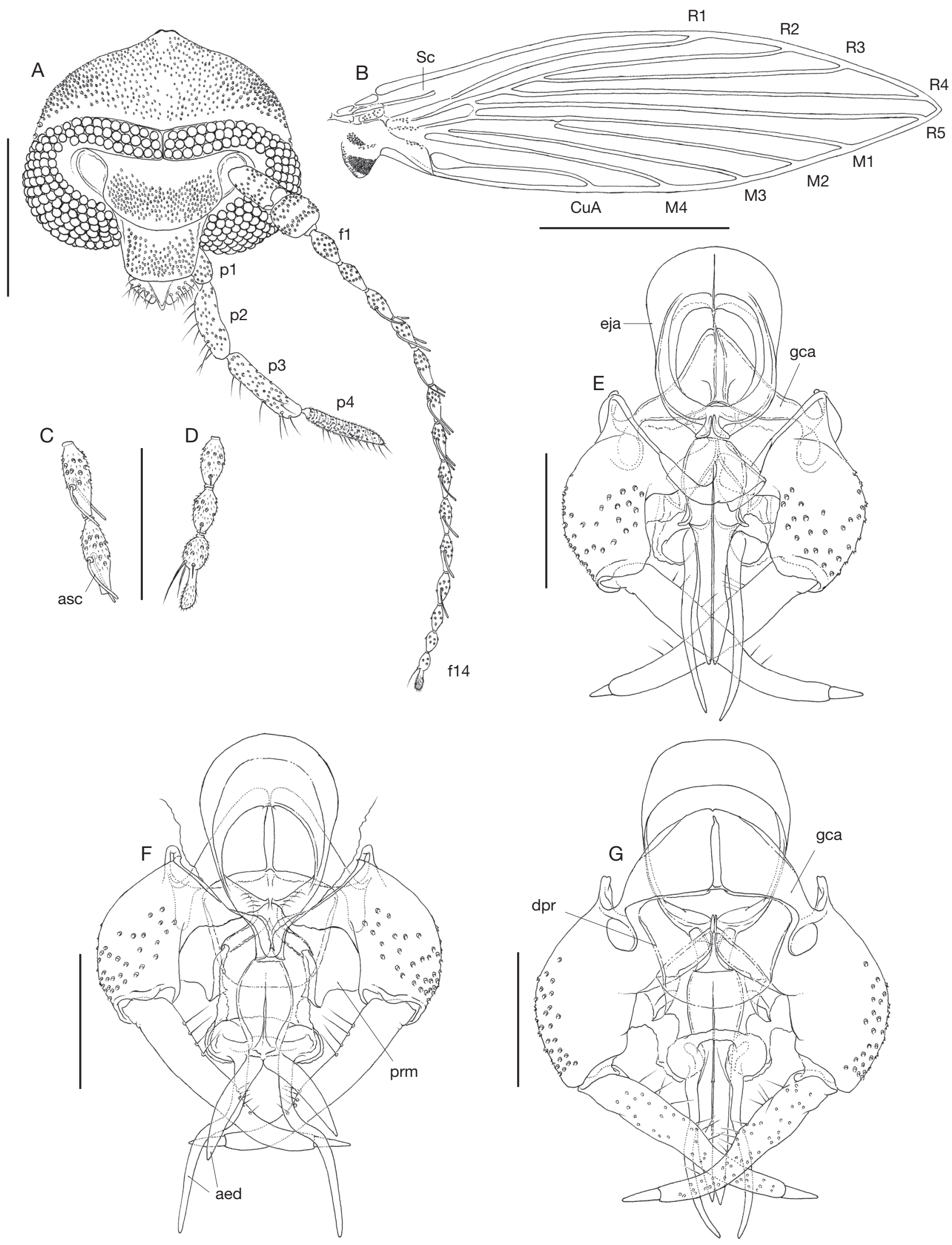

FIG. 1. - Polletomyia subulata n. gen., n. sp.: A, male head, frontal view; B, wing; C, male antennal flagellomeres 3-4, dorsal view; D, male antennal flagellomeres 12-14, dorsal view; E, male terminalia, epandrium removed, dorsal view; F, male terminalia, epandrium removed, aedeagal structure expanded, dorsal view; G, male terminalia, epandrium removed, aedeagal structure partly expanded, ventral view. Abbreviations: see Material and methods. Scale bars: A, 0.25 mm; B, $0.5 \mathrm{~mm}$; C-G, $0.1 \mathrm{~mm}$. 

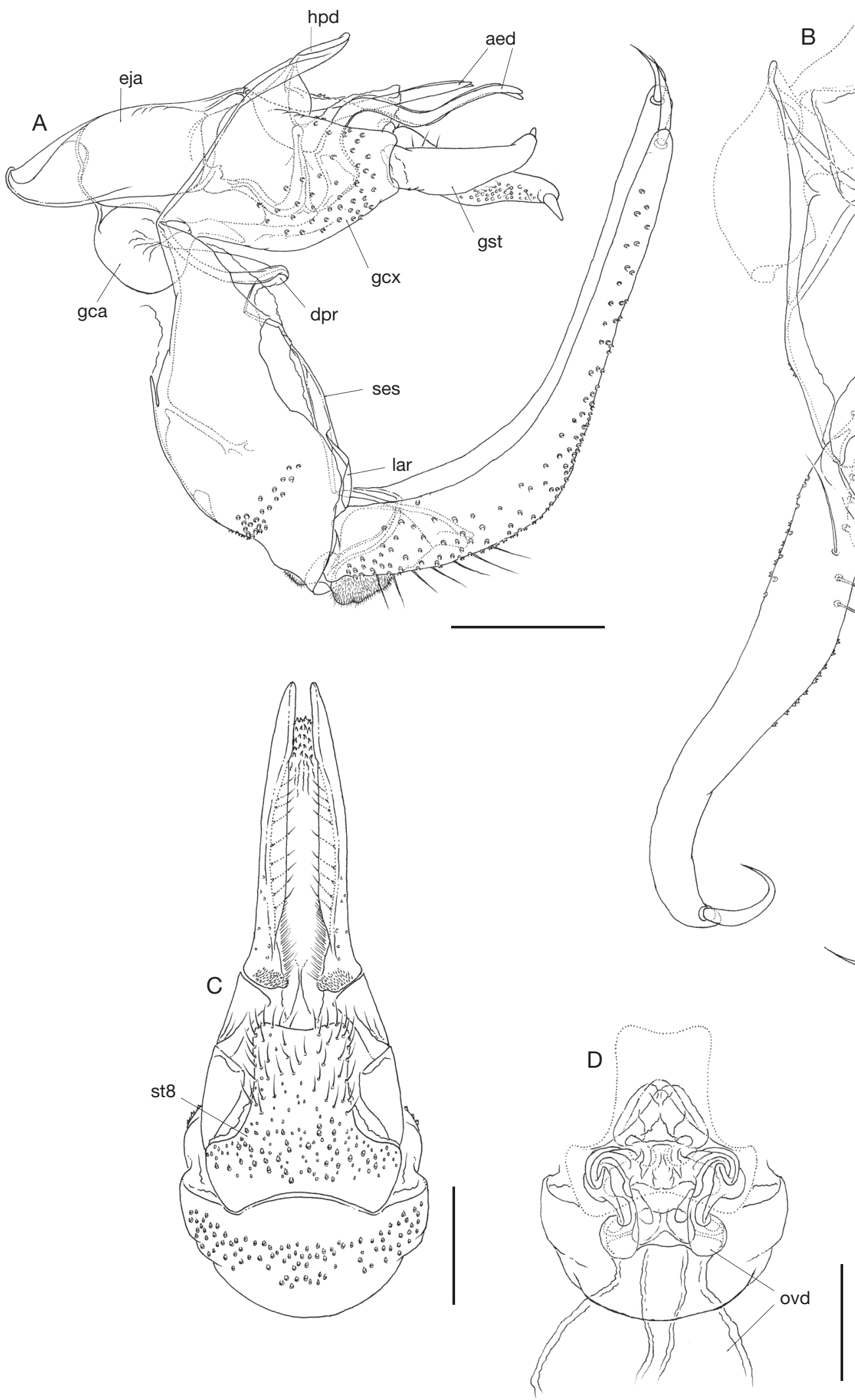

FIG. 2. - Polletomyia subulata n. gen., n. sp.: A, male terminalia, lateral view; B, male epandrium, proctiger and epandrial claspers, dorsal view; C, female terminalia, external structure, ventral view; $\mathbf{D}$, female terminalia, internal structure, ventral view. Abbreviations: see Material and methods. Scale bars: $0.1 \mathrm{~mm}$. 
Paratypes. French Guiana $\bullet 8$ ơ, 2 \%; same data as holotype; YPT; MNHN ( 4 o", 1 o), LACM (4 o" LACM 340591-340594, 1 ㅇ LACM 340595) • 2 o", 1 \%; site MIT-C-RBF2; 02¹4’03.4”N 542ㅇ'53.0"W; $29 \mathrm{~m}$ a.s.l.; lowland rainforest; 27.II-5.III.2015; Marc Pollet leg. (sample code: MITARAKA/126); BPT; LACM (o" LACM 340600-340601, 으 LACM 340602) - 3 o", 2 ㅇ; site MIT-C-RBF1; $02^{\circ} 14^{\prime} 10.8^{\prime \prime N}, 54^{\circ} 26^{\prime} 49.5^{\prime \prime W} ; 25 \mathrm{~m}$ a.s.l.; lowland rainforest; 27.II-8.III.2015; Marc Pollet leg. (sample code: MITARAKA/133); YPT; MNHN (2 ơ, 1 \%), LACM (1 ơ LACM 340596 , 1 아 LACM 340597) • 2 o ; site MIT-C-RBF1; 02 ${ }^{\circ} 14$ '10.8” N, $54^{\circ} 26^{\prime} 49.5^{\prime \prime W} ; 25 \mathrm{~m}$ a.s.l.; lowland rainforest; 27.II-8.III.2015; Marc Pollet leg. (sample code: MITARAKA/134); WPT; MNHN

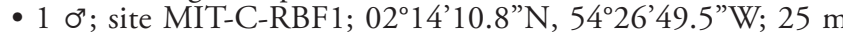
a.s.l.; lowland rainforest; 27.II-8.III.2015; Marc Pollet leg. (sample code: MITARAKA/135); BPT; MNHN • 3 o'; site MIT-C-RBF2,

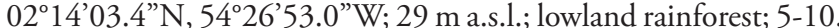
III.2015; Marc Pollet leg. (sample code: MITARAKA/137); BPT; MNHN (2 $\left.0^{7}\right)$, LACM (1 $0^{7}$ LACM 340598) • 1 o; site MIT-ARBF2; $02^{\circ} 14^{\prime} 12.5^{\prime \prime} \mathrm{N}, 54^{\circ} 27^{\prime} 08.1^{\prime \prime W} ; 28 \mathrm{~m}$ a.s.l.; lowland rainforest; 4-10.III.2015; Marc Pollet leg. (sample code: MITARAKA/149); BPT; LACM 340599.

ETYMOLOGY. - The specific epithet is derived form the Latin word "subulatus", meaning awl-shaped, in reference to the prominent, spiniform seta inserted at the apex of each gonostylus.

Diagnosis. - See above, Polletomyia n. gen.

DisTRIBUTION. - Currently known from multiple localities in the Mitaraka range of French Guiana.

HABITAT. - Little information regarding specific habitat is available; however, all specimens were collected in lowland rainforest.

\section{DESCRIPTION}

\section{Male}

Measurements, $(\mathrm{N}=5)$ head width $0.37 \mathrm{~mm}(0.34-0.40)$, head height $0.33 \mathrm{~mm}(0.30-0.34)$, wing length $1.70 \mathrm{~mm}$ (1.64-1.76), wing width $0.44 \mathrm{~mm}$. Head with vertex extended slightly posteriorly, eyebridge comprised of 3 facet rows, contiguous but slightly constricted at median. Antennae: scape cylindrical, about 1.5 times longer than wide; pedicel globular; flagellomeres fusiform, with paired ascoids on $\mathrm{f} 4 \mathrm{f} 7$, single ascoids on $\mathrm{f} 8 \mathrm{f11}$. Frons and clypeus distinctly divided; frontal scar patch bilobed posteriorly, contiguous medially. Mouthparts inconspicuous, obscured by clypeus, extending slightly beyond apex of palp segment 1; palpi typical of Psychodinae, with apical segment annulated; palp segment proportions: 1, 2, 2.18, 2.18; labellum about as wide as anterior margin of clypeus. Wing: strongly lanceolate; radial and medial fork positioned at a level basal to the apex of $\mathrm{CuA}$; $\mathrm{R}_{5}$ terminating in $\mathrm{C}$ posterior to wing apex; $\mathrm{M}_{2}$ incomplete at base; $\mathrm{CuA}$ conspicuously widened at base. Male terminalia: bilaterally symmetrical; hypandrium flat, band-like, arched posteriorly, fused with gonocoxites laterally; hypandrium in some specimens appearing folded along median (Fig. 1E); intersegmental membrane connecting between anterior margin of hypandrium and posterior margin of abdominal segment 8, covering base of ejaculatory apodeme; ejaculatory apodeme dorsoventrally compressed at base, dome-like at center, articulating posteriorly with aedeagal sclerites; aedeagus comprised of four blade-like sclerites (Fig. 1E-G) surrounded by a tubular membrane; innermost aedeagal sclerites spathiform, expanding dorsally in extended aedeagus; outer sclerites sinuous, longer than inner sclerites, expanding lateroventrally in extended aedeagus (Fig. 1F); parameres dorsoventrally compressed, flat, with pointed, hook-like projection posteromedially; gonostyli tapered gradually from base to apex, curved ventrally along apical half, appearing pitted ventrally; gonocoxites reniform, about two times as long as wide, setose, with setae alveoli laterally and dorsally; gonocoxal apodemes inflated, triangular in dorsoventral view, bulbous in lateral view, with dorsal paramere extending from posterior margin; subepandrial sclerite narrow, band-like, with lateral arms claw-shaped in dorsoventral view, linked to base of epandrial claspers; epandrium rectangular, narrowing posteriorly; epandrial claspers elongate, tapered, curved dorsally from base to apex, with single, setiform tenaculum inserted dorsoapically.

\section{Female}

Measurements, $(\mathrm{N}=3)$ head width $0.34 \mathrm{~mm}(0.32-0.36)$, head height $0.33 \mathrm{~mm}(0.32-0.34)$, wing length $1.84 \mathrm{~mm}$ (1.76-1.88), wing width $0.48 \mathrm{~mm}$ (0.44-0.52). Head and wing generally as in male; palp segment proportions: $1,2.50$, 3, 3. Terminalia: cerci elongate, heavily sclerotized, spatulate in lateral view, with numerous setae inserted on medial surface; posterior margin of sternum 8 bilobed, oviduct complex, ornate internally (Fig. 2D).

\section{Genus Myiomystax n. gen.}

\section{urn:Isid:zoobank.org:act:510873DE-6E58-4A95-9A5C-1D311DC38A70}

TyPE SPECIES. - Myiomystax trilineata n. gen., n. sp.

Illustrations. - Wing: Fig. 3A; Head: Fig. 3B; Male genitalia: Fig. 3C-D.

ETYMology. - This genus name is derived from the Latin "myia", meaning fly and "mystax", meaning mustache, in reference to the maxillary palps of the male. Before treating the specimens with $\mathrm{KOH}$, the setose palps of male $M$. trilineata n. gen., n. sp. gave the appearance of the fly having a prominent mustache.

DiAGNOSIS. - Male head: antennal flagellomeres 1-5 elongate, cylindrical; all flagellomeres lacking ascoids; clypeus elongate, expanded laterally, with lateral margins overlapping medial margins of eyes; palpi conspicuously elongate, with segment 1 hook-like, segment 4 inflated apically, capitate; palp segments with clusters of spatulate setae inserted dorsally and ventrally; palps folded behind head at rest. Male terminalia: bilaterally symmetrical; gonocoxites glabrous, without setae alveoli; aedeagal sclerites paired, laterally compressed, spatulate. Female head: maxillary palpi not elongated. Female terminalia: posterior margin of sternum 8 trilobed, with median lobe wider than flanking lobes; oviduct with microtrichia internally on membrane.

DisTRIBUTION. - Myiomystax n. gen. is currently known only from the Mitaraka range of French Guiana.

HABITAT. - Little information regarding specific habitat is available; however, all specimens were collected in lowland rainforest. 


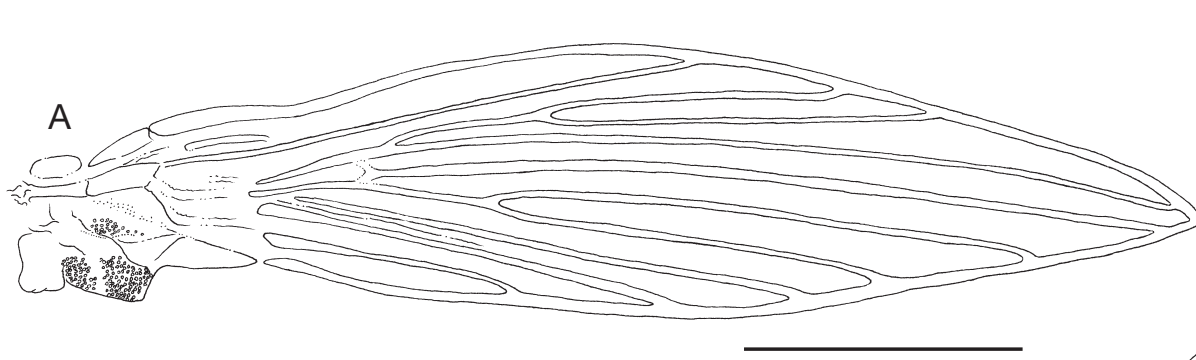

B

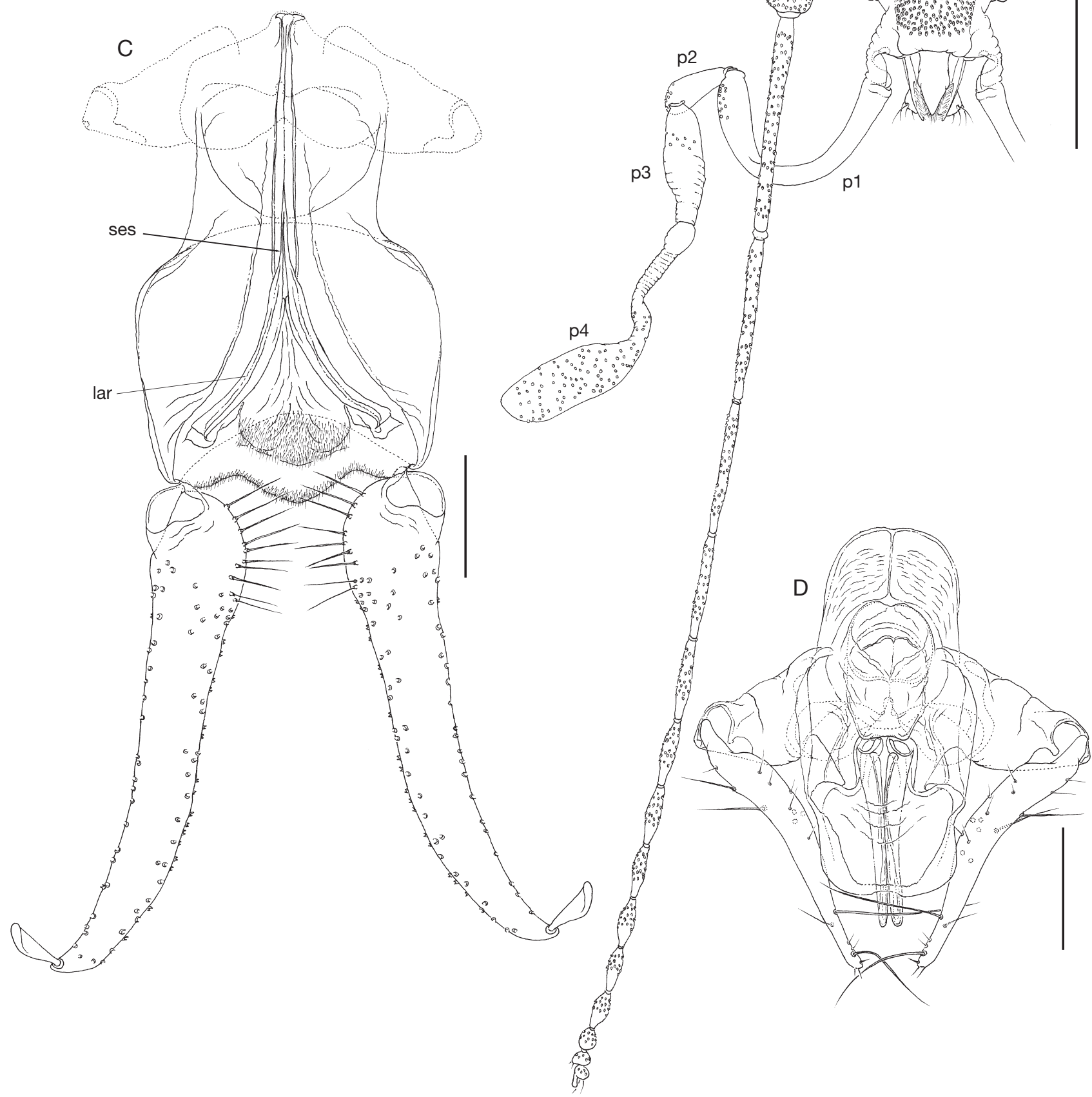

FIG. 3. - Myiomystax trilineata n. gen., n. sp.: A, wing; B, male head, frontal view; C, male epandrium, proctiger and epandrial claspers, dorsal view; D, male terminalia, epandrium removed, dorsal view. Abbreviations: see Material and methods. Scale bars: A, $0.5 \mathrm{~mm}$; B, $0.25 \mathrm{~mm}$; C-D, $0.1 \mathrm{~mm}$. 


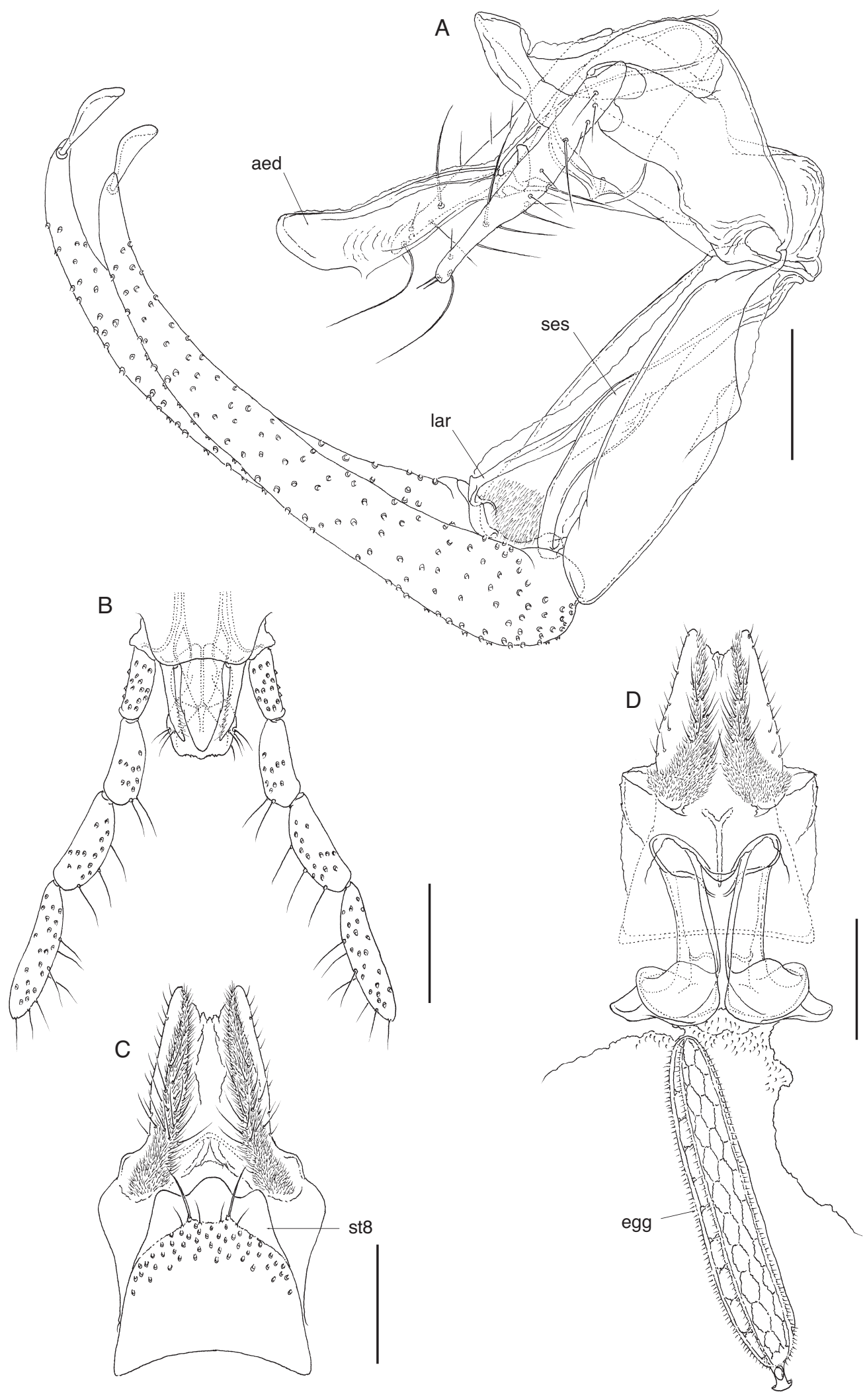

FIG. 4. - Myiomystax trilineata n. gen., n. sp.: A, male terminalia, lateral view; B, female mouthparts and maxillary palpi, frontal view; C, female terminalia, external structure, ventral view; D, female terminalia, internal structure and egg, ventral view. Abbreviations: see Material and methods. Scale bars: 0.1 mm. 

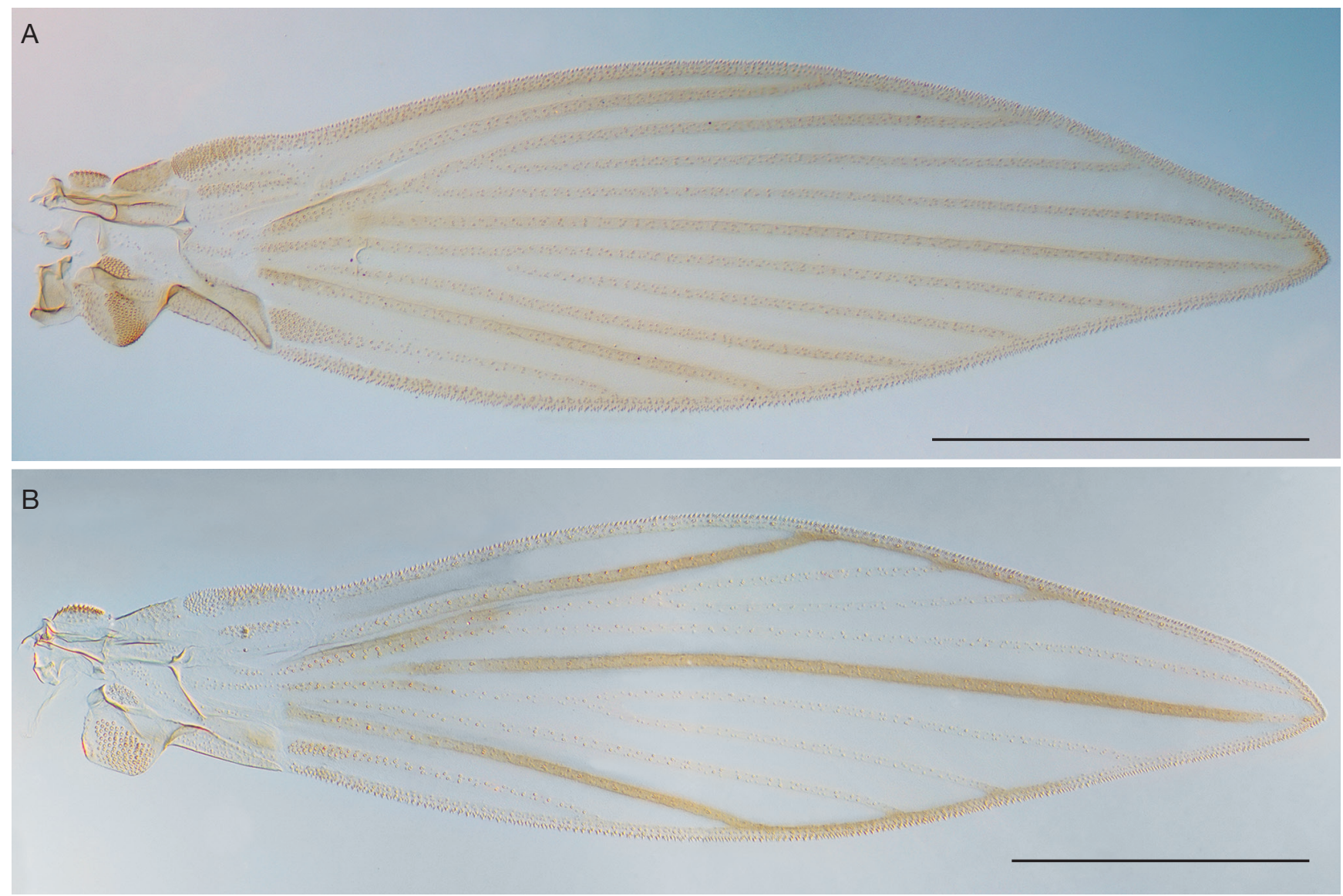

FIG. 5. - Photomicrographs of male wings: A, Polletomyia subulata n. gen., n. sp.; B, Myiomystax trilineata n. gen., n. sp. Scale bars: 0.5 mm

REMARKS

In contrast to Polletomyia n. gen., the relatively large size and light coloration of Myiomystax n. gen. make it possible to easily differentiate them in samples containing many psychodid genera. Moreover, while both genera have lanceolate wings, the latter is more distinctive due to several veins being darkly pigmented (Fig. 5). The unique wing of Myiomystax n. gen. also makes it easy to associate males and females of this genus. It remains to be determined whether these characteristics of the wing will be present in the wings of congeners, if any are discovered. Although less important compared to those of Polletomyia n. gen., accurate diagnosis of this genus is still dependent on examination of slidemounted male terminalia.

Myiomystax n. gen. males have a bilaterally symmetrical terminalia, with an aedeagus that extends as an open-close mechanism, much like Polletomyia n. gen. and Maruina. However, they differ from the other genera by having paired aedeagal sclerites as opposed to two pairs (as in Polletomyia n. gen.) or multiple aedeagal spines (as in Maruina). Myiomystax n. gen. males are also unique among these genera in that their gonocoxites lack setae.

\section{DESCRIPTION}

See below, Myiomystax trilineata n. gen., n. sp.
Myiomystax trilineata n. gen., n. sp.

(Figs 3; 4; 5B)

urn:Isid:zoobank.org:act:4BF6B1A7-8DED-4AFA-9184-A51145B25143

TYPE LOCALITY. — Guyane, Mitaraka.

TYPe MATERIAL. - Holotype. French Guiana - o'; Mitaraka, site MIT-C-RBF2; $02^{\circ} 14^{\prime} 03.4^{\prime \prime N}, 54^{\circ} 26^{\prime} 53.0^{\prime \prime} \mathrm{W} ; 29 \mathrm{~m}$ a.s.l.; lowland rainforest; 27.II-6.III.2015; YPT; Marc Pollet leg. (sample code: MITARAKA/125); specimen dissected, mounted on slide; MNHN. Paratypes. French Guiana • 1 \%; site MIT-C-RBF2; $02^{\circ} 14$ '03.4”N, 54 26'53.0"W; $29 \mathrm{~m}$ a.s.l.; lowland rainforest; 27.II.2015; Marc Pollet leg. (sample code: MITARAKA/018); SW; LACM 340595 - 4 o", 2 \%; same data as holotype; YPT; MNHN (2 o", 1 \&), LACM (2 ơ LACM 340603-340604, 1 ㅇ LACM 340605) • $10^{\prime \prime}, 2$ o; site MIT-C-RBF1; 02 ${ }^{\circ} 14^{\prime} 10.8^{\prime \prime} \mathrm{N}, 54^{\circ} 26^{\prime} 49.5^{\prime \prime} \mathrm{W}$; $25 \mathrm{~m}$ a.s.l.; lowland rainforest; 27.II-8.III.2015; Marc Pollet leg. (sample code: MITARAKA/133); YPT; MNHN (ơ, 1 \&), LACM (1 \& LACM 340606) - 9 ơ, 5 \%; site MIT-C-RBF2;

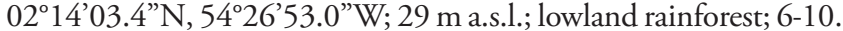
III.2015; Marc Pollet leg. (sample code: MITARAKA/136); YPT; MNHN (4 o", 3 ㅇ) , LACM (5 o" LACM 340607-340611, 2 우 LACM 340612-340613) • 1 \%; site MIT-C-RBF2; 02 14’03.4”N, $54^{\circ} 26^{\prime} 53.0^{\prime \prime W} ; 29 \mathrm{~m}$ a.s.l.; tropical wet forest (bas fond); $27 . \mathrm{II}-2$. III.2015; Marc Pollet leg. (sample code: MITARAKA/184); SLAM; MNHN • 1 \%; site different sites near base camp and along trails; 14.III.2015; Julien Touroult \& Eddy Poirier leg. (sample code: MITARAKA/191); SLAM; MNHN. 
ETYMology. - The specific epithet is derived form the Latin word "linea", meaning line, in reference to the three darkly pigmented wing veins present in this species.

DiagnOSIS. - See above, Myiomystax n. gen.

Distribution. - Currently known from multiple localities in the Mitaraka range of French Guiana.

HABITAT. - Little information regarding specific habitat is available; however, all specimens were collected in lowland rainforest.

\section{DESCRIPTION}

Male

Measurements, $(\mathrm{N}=4)$ head width $0.41 \mathrm{~mm}(0.38-0.44)$, head height $0.47 \mathrm{~mm}$ (0.44-0.48), wing length $2.17 \mathrm{~mm}$ (2.08$2.24)$, wing width $0.54 \mathrm{~mm}(0.52-0.56)$. Head with vertex extended slightly posteriorly, eyebridge comprised of 3 facet rows, contiguous but strongly constricted at median. Frons and clypeus distinctly divided; frontal scar patch bilobed posteriorly, contiguous medially; clypeus elongated laterally, with lateral margins overlapping medial margins of eyes. Antennae: scape cylindrical, about 2.5 times longer than wide; pedicel globular; flagellomeres 1-5 elongate, cylindrical; flagellomeres 6-11 fusiform; flagellomeres 12-14 reduced, bead-like; flagellomere 14 with apical process digitiform, setose, approximately as long as node; all flagellomeres lacking ascoids. Mouthparts extending slightly beyond base of palp segment 1; labellum about as wide as anterior margin of clypeus; palpi conspicuously elongate, with segment 1 hook-like; segment 2 clavate, inflating from base to apex; segment 3 elongate, inflated at midlength; segment 4 inflated apically, capitate; palp segments with clusters of spatulate setae inserted dorsally and ventrally; palps folded behind head at rest. Wing: strongly lanceolate; radial fork positioned slightly distal to apex of $\mathrm{CuA}$; medial fork positioned at the level of apex of $\mathrm{CuA} ; \mathrm{R}_{5}$ terminating in $\mathrm{C}$ posterior to wing apex; wing veins $R_{1}, R_{5}$ and $M_{4}$ pigmented brown, appearing more heavily sclerotized than other wing veins (Fig. 5B); costal vein with light pigment between apices of $R_{1}$ and $R_{3}$, $\mathrm{M}_{1}$ and $\mathrm{M}_{4}$; pigmented veins contrasting against other lightly colored wing veins. Male terminalia: bilaterally symmetrical; hypandrium flat, band-like, arched posteriorly, fused with gonocoxites laterally; intersegmental membrane connecting between anterior margin of hypandrium and posterior margin of abdominal segment 8 , covering base of ejaculatory apodeme; ejaculatory apodeme dorsoventrally compressed anterolaterally, dome-like at center, articulating ventrally with gonocoxal apodemes, posteriorly with aedeagal sclerites; aedeagus comprised of paired, laterally compressed sclerites, spatulate in lateral view; spatulate sclerites enveloped by tubular membrane; parameres not differentiated from aedeagus; gonostyli tapered, sinuous from base to apex (Fig. 3D), digitiform apically, setose, with paired, elongate setae inserted medially near apex (Figs 3D; $4 \mathrm{~A}$ ); gonocoxites glabrous, without setae alveoli (Figs 3D; $4 \mathrm{~A})$, cylindrical, about two times as long as wide; gonocoxal apodemes inflated, rounded in dorsoventral view, bulbous in lateral view, linked to subepandrial sclerite anteromedially; subepandrial sclerite narrow, divided medially, with puckered seam at median, with posterolateral arms ribbon-like, linked to base of epandrial claspers; epandrium rectangular along posterior half in dorsoventral view, anterior half narrowing abruptly; epandrial claspers elongate, tapered, curved dorsally from base to apex, with single, spatulate tenaculum inserted dorsoapically.

\section{Female}

Measurements, $(\mathrm{N}=4)$ head width $0.44 \mathrm{~mm}(0.42-0.46)$, head height $0.41 \mathrm{~mm}(0.40-0.42)$, wing length $2.16 \mathrm{~mm}$ (2.04-2.36), wing width $0.53 \mathrm{~mm}(0.52-0.56)$. Head mostly as in male. Antennae with flagellomeres 1 and 2 elongate, cylindrical, shorter than in male; apical flagellomeres missing in specimens observed. Mouthparts as in male; maxillary palpi more typical of Psychodinae, segments not elongated; palp segment proportions: $1,1.30,1,2.30$. Wing venation as in male. Terminalia: cerci conical in ventral view, with ventral surface covered by setulae, numerous setae inserted laterally and ventrally; posterior margin of sternum 8 trilobed, with median lobe wider than flanking lobes; oviduct with microtrichia internally on membrane.

\section{DISCUSSION}

Males of Maruinini exhibit geometry in their genitalia that is recognizable among most of the tribe's constituent genera. In addition to their unique general shape, specific structures such as the ejaculatory apodeme and the gonocoxal apodemes are interlinked in a way that distinguishes them from other Psychodinae. Genitalia morphology most similar to that described and illustrated above can also be found in genera such as Australopericoma Vaillant, 1971 (e.g. Bravo 2007: fig. 9), Alepia (e.g. Bravo 2008: figs 8-9), Tonnoira (e.g. Bravo et al. 2008: figs 16-18) and Maruina (e.g. Camico et al. 2019: figs 43, 44). In particular, the "ball and socket" construction, as discussed by Duckhouse (1990), can be identified; however, to see these structures clearly, it is necessary to examine both dissected and whole terminalia in dorsoventral and lateral view.

Another interesting character state in both genera described here is the bilateral symmetry of the male terminalia. In most genera of Maruinini, at least the aedeagus and parameres are strikingly asymmetrical; in some species, the gonopods are asymmetrical as well. Exceptions are as mentioned above. Prior to the description of Polletomyia n. gen. and Myiomystax n. gen., Maruina was the only genus of Maruinini of which all described species are known to have symmetrical genitalia. Furthermore, Maruina is the only other genus of Maruinini in which an open and close mechanism involving aedeagal and parameral sclerites has been reported (Vaillant 1963: fig. 2; Camico et al. 2019: figs 43-44).

Specimens of Polletomyia n. gen. and Myiomystax n. gen. collected during this study died with parts of their terminalia fixed in different positions. As shown previously for Maruina, it is evident that the aedeagal and parameral complex has developed into an evertable, or extendable (i.e., open and close) mechanism. Unfortunately, it is unclear how this mechanism works. The movable (i.e., extendable and expandable) nature of the aedeagus in P. subulata n. gen., n. sp. appears to be 
dependent on the anterior-posterior pivoting movement of the ejaculatory apodeme. As in some other Maruinini, the parameral sclerites appear to serve as a more stationary framework for the opening and closing aedeagus. This indicates that the parameres are serving to stabilize the terminalia in one position while the flies are in copula. Accurate descriptions of these structures depend on being able to differentiate the constituent sclerites. Unfortunately, in many groups of Psychodidae, fusions between the aedeagal and parameral sclerites have apparently occurred, making it difficult or impossible to tease apart these structures. Regardless, these are genus or species-level characters and thus, are of lesser importance for understanding relationships at a higher level. Despite the challenges posed by some characters, others (e.g. ejaculatory apodeme; gonocoxal apodemes) are less ambiguous and can be traced across genera. When ample material is available, Maruinini specimens should be prepared using various methods, such as clearing with cedarwood oil. This method eliminates fat body while leaving musculature intact, which will be necessary to fully understand the structure of the ejaculatory apodeme and how it interacts with the gonocoxal apodemes. This, in turn, could elucidate the process by which the aedeagal and parameral sclerites extend and retract.

Information on Neotropical Maruinini (= Setomimini) was synthesized in part by Quate \& Brown (2004), and many species of this group have since been described. Despite this, no phylogenetic revision of the group has been attempted. Many characters of the male and female genitalia are rich in information, but there is a need for clarification of homologies and identification of synapomorphies at higher levels rather than focusing only on autapomorphies found in genera and species.

\section{Acknowledgements}

The "Our Planet Reviewed" Guyane-2015 expedition in the Mitaraka range was funded by the European Regional Development Fund (ERDF), the Conseil régional de Guyane, the Conseil général de Guyane, the Direction de l'Environnement, de l'Aménagement et du Logement and by the Ministère de l'Éducation nationale, de l'Enseignement supérieur et de la Recherche. It was realized in collaboration with the Parc amazonien de Guyane and the Société entomologique AntillesGuyane. Greg Curler's wife, Amanda Jacobson, assisted with measuring specimens and provided the funding necessary for him to complete this study. Isaí Madriz expertly created the focus stacks and retouched the images in Figure 5. Lastly, thoughtful reviews from Danilo Cordeiro and Gunnar Kvifte helped to improve the original manuscript.

\section{REFERENCES}

Bravo F. 2007. - A new species of Australopericoma Vaillant (Diptera, Psychodidae) from the Brazilian semi-arid region. Biota Neotropica 7 (2): 325-328. https://doi.org/10.1590/S167606032007000200039

Bravo F. 2008. - Three new species of Alepia Enderlein (Diptera, Psychodidae, Psychodinae) from the Brazilian semi- arid region. Zootaxa 1805: 52-60. https://doi.org/10.11646/ zootaxa.1805.1.2

Bravo F., Chagas C. \& Alves V. R. 2008. — Description of two new species of Tonnoira Enderlein from caves in the Brazilian Amazon and comments about the taxonomic status of Tonnoira plumaria Quate (Diptera, Psychodidae, Psychodinae). Zootaxa 1916: 62-68. https://doi.org/10.11646/zootaxa.1916.1.4

Camico J., Cordeiro D. \& Chagas C. 2019. - Maruina Muller, 1895 (Diptera: Psychodidae): description of four new species from Brazil, with revised diagnoses for the genus and subgenera. Zootaxa 4652 (2): 296-316. https://doi.org/10.11646/zootaxa.4652.2.4

Cumming J. M. \& WooD D. M. 2017. — Adult morphology and terminology in KirK-Spriggs A. \& Sinclair B. (eds.) Manual of Afrotropical Diptera. Volume 1. South African National Biodiversity Institute, Pretoria, $425 \mathrm{p}$.

Curler G. R. \& Moulton J. K. 2012. — Phylogeny of psychodid subfamilies (Diptera: Psychodidae) inferred from nuclear DNA sequences with a review of morphological evidence for relationships. Systematic Entomology 37: 603-616. https://doi. org/10.1111/j.1365-3113.2012.00634.x

Dos Santos C. B. \& Curler G. R. 2014. - Four new species of Tonnoira Enderlein (Diptera: Psychodidae, Psychodinae) from the Brazil Atlantic forest. Zootaxa 3760: 463-470. https://doi. org/10.11646/zootaxa.3760.3.13

DuckHouse D. A. 1990. - The Australasian Genera of Pericomoid Psychodidae (Diptera) and the Status of Related Enderlein Genera. Invertebrate Taxonomy 3: 721-746.

Galati E. A. B. 2019. - Morfologia e terminologia de Phlebotominae (Diptera: Psychodidae). Classificação e identificaçáo de táxons das Américas. Vol I. Apostila da Disciplina Bioecologia e Identificação de Phlebotominae do Programa de Pós-Graduacáo em Saúde Pública. Faculdade de Saúde Pública da Universidade de Sáo Paulo, São Paulo, 133 p. http://www. fsp.usp.br/egalati

KRZEMINSKI W. \& KRZEMIŃSKA E. 2003. - Triassic Diptera: descriptions, revisions and phylogenetic relations. Acta Zoologica Cracoviensia 46: (suppl.-Fossil Insects): 153-184.

Kvifte G. M. \& Wagner R. 2017. - Psychodidae (Sand Flies, Moth Flies or Owl Flies) in KIRK-Spriggs A. \& Sinclair B. (eds.) Manual of Afrotropical Diptera. Volume 2. South African National Biodiversity Institute, Pretoria, 936 p.

Quate L. W. \& BRown B. V. 2004. - Revision of Neotropical Setomimini (Diptera: Psychodidae: Psychodinae). Contributions in Science, Natural History Museum of Los Angeles County 500: $1-120$.

Satchell G. H. 1955. - Two new subgenera of Psychodidae (Diptera) from Jamaica, with descriptions of five new species. Annals and Magazine of Natural History 12: 85-93. https://doi. org/10.1080/00222935508651831

Touroult J., Pollet M. \& Pascal O. 2018. - Overview of Mitaraka survey: research frame, study site and field protocols, in Touroult J. (ed.), “Our Planet Reviewed” 2015 large-scale biotic survey in Mitaraka, French Guiana. Zoosystema 40 (13): 327-365. https://doi.org/10.5252/zoosystema2018v40a13. http:// zoosystema.com/40/13

VAillant F. 1963. — Les Maruina d'Amérique du Nord (Diptera, Psychodidae). Bulletin de la Société entomologique de France, Paris 68: 71-91.

Young D. G. \& DunCAN M. A. 1994. - Guide to the identification and geographic distribution of Lutzomyia sand flies in Mexico, the West Indies, Central and South America (Diptera: Psychodidae). Memoirs of the American Entomology Institute 54: $1-881$.

Submitted on 10 January 2018; accepted on 15 October 2019; published on 7 April 2020. 